DOI: http://dx.doi.org/10.18764/2358-4319.v10n1p11-33

\title{
A linguagem da imaginação no pensamento da educação
}

\author{
Alberto Filipe Araújo' \\ Rogério de Almeida ${ }^{2}$
}

\section{RESUMO}

O objetivo deste artigo é estudar a linguagem da imaginação a partir da investigação da metáfora e do símbolo e de seus usos no pensamento da educação, com suas metáforas hortícolas devedoras do simbolismo vegetal. A atuação do poder imaginante das metáforas vivas (Paul Ricoeur) nos conduz ao passo seguinte, que busca compreender a dinâmica da imaginação simbólica no psiquismo imaginante (Gaston Bachelard, Gilbert Durand e Wunenburger). Conclui o artigo a articulação dos conceitos estudados a uma pedagogia da imaginação e à formação imaginante do sujeito, de modo que a linguagem da imaginação possa efetivamente contribuir com o pensamento da educação.

Palavras-chave: Antropologia do Imaginário. Metáfora e símbolo. Imaginação simbólica. Pedagogia da imaginação.

\section{The language of imagination in education thought}

\section{ABSTRACT}

The aim of this paper is to study the language of imagination with the research of the metaphor and symbol and its uses in education thought, and its horticultural metaphors connected to vegetable symbolism. The acting of imaginative power of the living metaphors (Paul Ricoeur) leads us to the next step, which aims to understand the dynamics of symbolic imagination in imaginative psyche (Gaston Bachelard, Gilbert Durand and Wunenburger). Concludes the paper the articulation of concepts defined to a pedagogy of imagination and the imaginative formation of the subject, so that the language of imagination can effectively contribute to education thought.

1 Doutor em Educação. Professor catedrático da Universidade do Minho, Braga - Portugal. Experiência na área de Educação, com ênfase em Filosofia da Educação. Autor e co-autor de numerosos trabalhos, em Portugal e no estrangeiro, dedicados ao tema do Imaginário e Imaginário Educational. E-mail: afaraujo@ie.uminho.pt

2 Doutor em Educação. Professor associado da Faculdade de Educação da Universidade de São Paulo. Coordenador do Lab_arte e do GEIFEC. Email: rogerioa@usp.br 
Keywords: Anthropology of the Imaginary. Metaphor and symbol. Symbolic imagination. Pedagogy of imagination.

\section{El lenguaje de la imaginación en el pensamiento de la educación}

\section{RESUMEN}

El objetivo de este artículo es estudiar el lenguaje de la imaginación a partir de la investigación de la metáfora y del símbolo y de sus usos en el pensamiento de la educación, con sus metáforas hortícolas deudoras del simbolismo vegetal. La actuación del poder imaginante de las metáforas vivas (Paul Ricoeur) nos conduce al paso siguiente, que busca comprender la dinámica de la imaginación simbólica en el psiquismo imaginante (Gastón Bachelard, Gilbert Durand y Wunenburger). Concluye el artículo la articulación de los conceptos estudiados a una pedagogía de la imaginación ya la formación imaginante del sujeto, de modo que el lenguaje de la imaginación pueda efectivamente contribuir con el pensamiento de la educación.

Palabras clave: Antropología del Imaginario. Metáfora y símbolo. Imaginación simbólica. Pedagogía de la imaginación.

Sem imaginação figurativa, a educação não seria nada mais que um fabricação em série, que uma repetição mecânica do mesmo exemplar de humanidade. Assim a educação aparece como inseparável de uma formação da imaginação, de um domínio do poder de apropriar-se e de tornar as imagens mais pregnantes. (WUNENBURGER, 1993, p. 62-64).

\section{A metáfora e o símbolo como linguagem da imaginação}

A metáfora na interpretação hermenêutica constitui campo privilegiado para a reflexão do papel que desempenha na educação e suas mais diversas manifestações, como as teorias educativas e as práticas discursivas e pedagógicas. Se, por um lado, a educação não pode se afirmar sem o poder da metáfora, por outro a metáfora surpreende-nos na medida em que surge como uma das vias privilegiadas para o símbolo e a 
imaginação. Assim, e neste contexto, ressalta-se a importância heurística da "metáfora viva" (Paul Ricoeur) na sua abertura ao símbolo e ao simbolismo vegetal que dá forma à metáfora agrícola tão representativa e presente nos discursos e textos sobre a educação. No entanto, a relação metáfora-símbolo não se limita ao seu potencial heurístico, nem hermenêutico, mas se caracteriza por sua inesgotável riqueza semântica. Permanece, entretanto, uma questão: seria possível formar o sujeito imaginante sem recorrer a uma pedagogia da imaginação?

A metáfora é encarada como uma função expressiva geradora de invenção e de inovações semânticas em que o jogo da semelhança (similaridade) e da dissemelhança está sempre presente (WUNENBURGER, 2012). Uma metáfora, para tornar-se "viva" (RICOEUR, 1997), tem que surpreender, tem que produzir uma inovação semântica pertinente. Para tanto, é preciso admitir que o sentido figurado precede o próprio, que o sentido equívoco é mais importante que o unívoco e que a conotação, que promove associações subjetivas, tem mais valor que a denotação. Dito isto, não significa que a metáfora na educação não possua uma necessidade lógico-cognitiva que não seja devidamente considerada na reflexão filosófico educacional.

Na metáfora agrícola, à semelhança da metáfora em geral, a experiência visual é indissociável da imagem verbalizada ou linguística. Nesta perspectiva, a imagem metaforizante é uma imagem ora espontânea, ora produto mais ou menos racionalizado por parte daquele que a inventa e nunca é isenta de carga afetiva e mesmo policromática. A metáfora, como uma espécie de "hormona de sentido", Bachelard diria "hormona da imaginação" ${ }^{3}$, está naturalmente a serviço do psiquismo enquanto catalisadora do ato imaginativo que reenvia do pequeno para o grande e vice-versa, troca o todo pela parte e vice-versa, enfim não descura também a relação entre o microcosmo e macrocosmo.

Sendo a imaginação, em si, expressividade, ela carece da criatividade plástica e verbal da metáfora, do seu poder polifônico-verbal

3 As metáforas têm na sua base imagens "primitivas", "primeiras", "fundamentais" ou "prínceps" an-históricas e universais inconscientes produzidas nas profundidades noturnas do psiquismo (exemplo de imagens "primeiras": a árvore, a flor, o cristal, o refúgio/casa, a imensidade, o rochedo, a forja, o fogo, a água, o ar, a terra, o voo do pássaro, etc.): "elas [as imagens] constituem, contudo, núcleos de significações e de afetos, verdadeiros germes sintéticos do onirismo, que Bachelard chamará, a partir de A Terra e os devaneios do repouso, à semelhança de C. G. Jung, arquétipos supra-pessoais e universais" (WUNENBURGER, 2012, p. 107). 
para se manifestar e para melhor se dar a conhecer. Pelo seu uso o sujeito tonifica-se e cresce psiquicamente:"Imagens literárias e metáforas são, em todo o caso, um fator maior de dinamização psíquica, capaz de tonificar o sujeito" (WUNENBURGER, 2012, p. 108). Esta valorização da metáfora tem a ver com sua simbolização viva, com a sua função de abertura para o símbolo e, como tal, a metáfora aqui se afasta do mero procedimento retórico do "ilustrar melhor" para aceder a um estatuto de "mais ser" (BACHELARD, 1961). Por sua vez, este estatuto tem como seu corolário a capacidade que a metáfora tem, em si, de gerar sentidos novos, ou seja, de produzir um "excesso" de sentido novo que abre novos horizontes antes fechados e ocultos pelo "pequeno" sentido, isto é, pela pragmática do sentido literal e pela denominação. Aquilo que importa sublinhar, a pertinência e a qualidade de uma metáfora, vê-se pela inovação ou impertinência semântica que ela produz, e quanto maior for essa inovação, tanto maior é a informação nova que ela dá acerca da realidade: uma metáfora "oferece uma nova informação [...] diz-nos algo de novo acerca da realidade" (RICOEUR, 1987, p. 64)4. A este "excesso" de inovação semântica corresponde aquilo que Paul Ricoeur (1987, p. 64) designa por uma "verdadeira criação de sentido" e esta criação, por sua vez, é o traço marcante da chamada "metáfora viva": "As metáforas vivas são metáforas de invenção, em cujo interior a resposta à discordância na frase é uma nova extensão do sentido" (WUNENBURGER, 2012, p. 109-111). A metáfora como "forma bizarra de predicação" (RICOEUR,1987) redescreve a realidade, ou seja, "mostra-nos novas possibilidades de articulação e conceptualização da realidade" (RICOEUR,1987, p. 69-80), e, ao fazê-lo, abre-nos as portas da ficção como instância fundamental da imaginação ${ }^{5}$.

4 A este respeito, ouçamos Paul Ricoeur: "Assim como o sentido literal se tem de abandonar para que o sentido metafórico possa emergir, assim também a referência literal deve desaparecer para que a função heurística possa operar a sua redescrição da realidade" (RICOEUR, 1987, p. 79).

5 O tema da força heurística da ficção é importante na teoria da imaginação porque ajuda a ultrapassar a questão da enunciação metafórica ter um sentido sem ter uma referência explícita, ostensiva. Todavia, isso não significa que ela seja destituída de referência de segundo grau, também chamada de referência primordial por Ricoeur. $\mathrm{O}$ afirmado significa que o discurso poético exprime a nossa pertença ao mundo da vida e estabelece uma ligação ontológica do nosso ser aos outros seres e ao ser enquanto tal. Numa palavra, a referência de segundo grau é aquilo que se deixa dizer. Este ponto implica uma consequência importante para a teoria da imaginação na medida em que a ficção, ao designar "o nãolugar em relação a toda a realidade" (RICOEUR, [1986], p. 221), não significa, contudo, que não a vise, constituindo assim um novo "efeito de referência". Este novo "efeito de referência", como salienta Ricoeur, não é mais do que o poder da ficção de redescrever a realidade e este poder aparece na sua máxima expressão sob a figura da utopia que nos vai ocupar 
Pela metáfora"viva" é a emergência de sentido que nasce e aflora no psiquismo imaginante do sujeito pelo estilhaçar do sentido próprio a favor do sentido figurado, do convencional em favor do excêntrico e da ordem em favor da transgressão. É, portanto, neste estilhaçar do sentido próprio a favor de um campo semântico inovador que a metáfora se abre ao mundo do símbolo:

Porque o metafórico acha-se assim bem conduzido na esteira da simbólica, modo específico pelo qual um pensamento, apoiando-se inteiramente sobre os constrangimentos sintáticos e semânticos da língua, produz arranjos verbais que visam de imediato um segundo sentido, figurado, latente, que abre sobre uma interpretação ambígua e pressupõe uma espécie de transcendência do sentido (Sinn) em relação à única significação denotativa (Bedeutung), segundo a distinção introduzida por Frege. A metáfora viva enriquece-se, portanto, das virtudes do símbolo enquanto ele é 'o movimento do sentido primário que nos faz participar do sentido latente e assim nos assimila ao simbolizado sem que nós possamos dominar intelectualmente a similitude' [Paul Ricoeur, Finitude et culpabilité, II: la symbolique du mal, p. 22]. A metáfora parece portanto ter progressivamente tomado o lugar da função simbolizante que realmente garante a sua consistência e sua eficácia pela sua capacidade em reunir planos de significação separados (WUNENBURGER, 2012, p.111, 2002, p. 36).

Constata-se deste modo que a metáfora abre caminho para o símbolo e esta abertura permite, por conseguinte, entrar no âmago da imaginação, seja ela criadora (mundo das metáforas e dos símbolos vivos) ou reprodutora (mundo das metáforas mortas e dos estereótipos ou sintemas na terminologia de René Alleau (1982). A relação metáfora-

em seguida. No entanto, sublinhe-se que redescrever é ainda descrever, cabendo, pois, à imaginação ultrapassar, através de uma poética da ação, a mera "reconstrução com valor descritivo", não se ater à sua função mimética mesmo aplicada à ação, bem como assumir a sua função projetiva que pertence ao próprio dinamismo do agir (RICOEUR, [1986], p. 223). Esta função projetiva é nuclear na utopia como uma das dimensões do imaginário social, porque é graças a esta função que o sujeito se sente incentivado a antecipar virtualmente o futuro pelo poder-fazer. Não há de facto ação sem imaginação e, consequentemente, sem o halo utópico, pois é este que, nos planos do projeto, da motivação e do próprio poder fazer, estimula à transformação mais ou menos radical: "É, de facto, nesta imaginação antecipadora do agir que eu 'tento' diversos cursos eventuais de acção e que eu 'jogo', no sentido exato da palavra, com os possíveis práticos" (RICOEUR, [1986], p. 223). 
símbolo conduz-nos ao sanctum sanctorum da imaginação, enquanto matriz da criatividade (WUNENBURGER, 2012), em que o papel da metáfora, ao trazer algo de novo acerca da realidade, ao produzir novas informações e inovações semânticas, impulsiona a imaginação a inventar "vida nova", a inventar espírito novo: "ela abre os olhos que têm tipos novos de visão. Ela verá se ela tem 'visões"' (BACHELARD, 1993).

A imaginação deve bastante à relação metáfora-símbolo (RICOEUR, 1987) porque tanto a metáfora quanto o símbolo funcionam como uma espécie de "hormonas" da imaginação: a metáfora representa o "momento semântico do símbolo" (RICOEUR,1987, p. 66-69) e é o reagente adequado para fazer aparecer o "momento não semântico do símbolo" (RICOEUR,1987, p. 69-75). Embora a metáfora se comporte como a condição necessária de nos franquear o caminho do símbolo, tal não significa que o símbolo se confunda com ela pela simples razão que o símbolo possui, ao contrário da metáfora, um "carácter ligado", um "carácter pré-verbal", representa poder, força e eficácia do cosmos e da vida e do próprio sentimento: "O carácter ligado dos símbolos é que constitui toda a diferença entre um símbolo e uma metáfora. A última é uma invenção livre do discurso; o primeiro está vinculado ao cosmos" (RICOEUR, 1987, p.73).

Uma das melhores ilustrações da natureza do símbolo, enquanto estrutura semântica de duplo sentido (semântico-verbal e não semântico-não verbal) dá-se por intermédio do simbolismo. Aqui interessa realçar como a metáfora agrícola conduz ao simbolismo vegetal, enquanto representante deste poder cósmico e cujas características são a hierofania vegetal e a vida biocósmica, e é, por conseguinte, pela compreensão deste trânsito que esperamos aproximar-nos da imaginação no discurso ou no texto educacional e pedagógico. Uma metáfora hortícola é uma porta aberta para o símbolo (RICOEUR, 1988) que pode não ser apenas "viva", e esta o é, quando produz uma inovação semântica inesperada ou inabitual (RICOEUR, 1997, 1987), como pode igualmente ser prometedora do ponto de vista do simbolismo vegetal: "Através da vegetação, é a vida inteira, é a natureza que se regenera por múltiplos ritmos, que é 'honrada', promovida, solicitada. As forças vegetativas são uma epifania da vida cósmica" (ELIADE, 1994, p. 404).

Daniel Hameline e Nanine Charbonnel colocam a metáfora agrícola sob o signo do "é como..." da similitude (HAMELINE, 1986), do"ver 
como"da similitude (CHARBONNEL, 1993). Por outras palavras, a metáfora agrícola aparece do lado da similitude, porquanto compara entidades heterogêneas e pertencentes a gêneros ontológicos diferentes, como é exemplo à comparação que Freinet faz entre a criança e um grão de trigo (CHARBONNEL, 1994). A metáfora hortícola, tal como a entende Daniel Hameline, serve de um meio pertinente para exprimir a analogia, a similitude entre o crescimento natural da planta e o crescimento da criança, entre "os elementos do comparado (o ensino) e do comparante (o alimento da planta)." (CHARBONNEL, 1994, p. 54):

A educação é efetivamente uma cultura da criança que, à semelhança de outros seres vivos, vegetais ou animais, traz em si-mesmo as fontes e os mecanismos motores do seu crescimento e das aquisições. A metáfora hortícola é uma constante de todas as correntes pedagógicas que opuseram o lugar-comum do vivente a fazer (ou deixar) crescer, ao lugar-comum do produto (mecânico, mas mais frequentemente social) à modelagem.

A presença da metáfora agrícola, ligada ao simbolismo vegetal, nunca foi indiferente aos adeptos da "Educação Nova", como é o caso de Célestin Freinet, que se serve dela na sua obra educativo-pedagógica para melhor ilustrar suas ideias sobre o comportamento humano. Freinet escreve a sua "psicologia sensível" para melhor fundar uma pedagogia que visa à ação, que pretende aconselhar a prática da boa ação. Ao longo do seu Essai de psychologie sensible é recorrente, em passagens decisivas, que um mesmo vegetal apareça e este não é mais do que uma árvore que é, por sua vez, comummente exaltada enquanto modelo energético e modelo conceitual:

Se o indivíduo fosse suficientemente forte e harmoniosamente constituído, se as condições exteriores fossem, no máximo favoráveis, ele cresceria normalmente segundo sua natureza e as leis específicas da sua formação. Ele seria como uma árvore que cresce num lugar benéfico, regularmente exposta ao sol, bem alimentada, ao abrigo dos grandes ventos, e que ergue o seu tronco, espalha os seus ramos e galhos segundo a distribuição que lhe é própria, numa harmonia que é normalmente perfeita (FREINET, 1994, p. 387). 
Nós compararemos o organismo humano à árvore que sai da terra, mais ou menos vigorosa porque mais ou menos bem enraizada e alimentada, e que crescerá tanto melhor se ela provém de uma boa semente, e que ela se encontre num solo que lhe convém porque ele a alimenta da sua seiva específica. Se ela emerge da terra nas melhores condições, ela organiza normalmente a sua vida segundo as leis da sua espécie (FREINET,1994, p. 416-417).

$\mathrm{Na}$ base destas citações de Célestin Freinet, em que o ser humano é comparado ou assemelhado a uma árvore, assiste-se, pelo menos aparentemente, à comparação de duas realidades heterogêneas e este tipo de comparação recebe o nome de similitudo porque, na verdade, e o conjunto da sua obra Ensaio de Psicologia Sensível assim o parece apontar, a essas mesmas realidades heterogêneas na aparência subsistem entidades homogêneas, porque ambas (criança e árvore) obedecem às "leis da Natureza". Mas aqui o que importa enfatizar é que para além do regime semântico dos enunciados metafóricos (expressivo, cognitivo ou praxeo-prescritivo) (CHARBONNEL, 1991) nos quais se possam inscrever as citações acima referidas, é a possibilidade de fazer uma leitura da metáfora agrícola mais de tipo hermenêutico, que postula um "esquematismo transcendental" do imaginário (DURAND, 1984).

Tendo em conta estas observações, salientamos que o ponto de vista hermenêutico nos dá margem a interpretar a metáfora agrícola de um modo mais radical, como aliás o estudo de Paul Ricoeur (1987) dedicado à relação metáfora-símbolo parece indicar, e aqui radical significa procurarmos as raízes deste tipo de metáfora nos símbolos da vegetação e nos seus ritos de renovação. Assim, à luz desta perspectiva, se aceitamos que num primeiro momento as imagens agrícolas e naturalistas usadas por Célestin Freinet sirvam somente para, em nome do "triunfo da similitude" (HAMELINE, 1986), melhor ilustrar e consagrar o substrato filosófico-educacional do seu pensamento contaminado pelo naturalismo e pelos princípios da higiene natural, já num segundo momento perguntamo-nos se não nos devíamos interrogar se a metáfora agrícola não nos conduzirá a um substrato mais fundo, mais abaixo, mais radical, que é domínio umbroso e multívoco do símbolo aquilo que Paul Ricoeur identificou com o "momento não semântico de um símbolo" (RICOEUR, 1987, p. 69-75) e, muito particularmente, do simbolismo vegetal (ARAÚJO, 2004; ELIADE, 1994). E por simbolismo 
vegetal entendemos o símbolo da árvore que se articula em torno da ideia de Cosmos vivo em contínua regeneração e cujos significados mais característicos são, por um lado, "a árvore-imagem do cosmos; [...] a árvore-símbolo da vida, da fecundidade inesgotável, da realidade absoluta; [...] a árvore símbolo da ressurreição da vegetação da Primavera e da 'regeneração' do ano" (ELIADE, 1994, p. 337) e, por outro o

Símbolo da vida, em perpétua evolução, em ascensão para o céu, a árvore evoca todo o simbolismo da verticalidade: [...] A árvore põe também em comunicação os três níveis do cosmos: o subterrâneo, com as suas raízes abrindo caminho nas profundezas onde penetram; a superfície da terra, como o tronco e os primeiros ramos; as alturas, com os seus ramos superiores e o seu ponto mais alto atraídos pela luz do céu. [...] a árvore é universalmente considerada como um símbolo das relações que se estabelecem entre a terra e o céu (CHEVALIER; GHEERBRANT, 1994, p. 89; BIERDERMANN, 1996, p. 42-46).

Se é verdade que o símbolo vegetal carece da metáfora agrícola para melhor se dar a ver, pois há mais na metáfora do que no símbolo, "no sentido que ela traz à linguagem a semântica implícita no símbolo, o que permanece confuso no símbolo" (RICOEUR, 1987, p.80), não é menos verdade que a metáfora agrícola torna-se "viva"6 quando ela absorve e reflete a "aura" do simbolismo vegetal:

A metáfora é o procedimento linguístico - forma bizarra de predicação - dentro do qual se deposita o poder simbólico. O símbolo permanece um fenómeno bidimensional na medida em que a face semântica se refere à não semântica. O símbolo está ligado de um modo que a metáfora não está. Os símbolos têm raízes. Os símbolos mergulham na experiência umbrosa do poder. (RICOEUR, 1987, p. 81).

E é na condição da própria metáfora assumir-se como "viva" que interessa à imaginação, por ela ser metáfora de invenção dotada

6 Pensamos na obra de Paul Ricoeur intitulada La Métaphore vive, enquanto Hans Blumenberg prefere usar o conceito de "metáfora absoluta" identificada com o mito (Blumenberg, 2003, p. 165-170), e Gaston Bachelard utiliza de "metáfora axiomática" para designar um tipo de metáfora de excelência e absoluta, que funciona, pelo menos assim nos parece, como um dos mais fortes reagentes da imaginação a par dos quatro elementos (terra, água, fogo e ar) caracterizados como "hormonas da imaginação" (BACHELARD, 2004, p. 19). 
de um potencial criativo e cognitivo significativamente atuantes. Por outras palavras, este tipo de metáfora redescreve a realidade, produz inovação semântica, ou seja, cria uma nova pertinência semântica. Não obstante, é preciso ir além do domínio da frase para atingirmos o nível do discurso (poema, narrativa, ensaio etc.) que é o nível hermenêutico propriamente dito. É, portanto, neste nível que entramos no domínio da ficção instaurado pelo poder da metáfora de "redescrever": "A metáfora apresenta-se assim como uma estratégia de discurso que, preservando e desenvolvendo o poder criador da linguagem, preserva e desenvolve o poder heurístico desenvolvido pela ficção" (RICOEUR, 1997, p. 10). A metáfora (e é sempre da viva que falamos no sentido que Ricoeur lhe atribui) é um medium privilegiado para introduzir-nos nas modelizações figurativas que recusam quer as determinações sensíveis do percepto (o dado da percepção), quer as determinações abstratas do conceito. Por outras palavras, a metáfora resgata da imaginação as suas produções de ficções e de representações irreais, que representam sempre um perigo para um conhecimento que se pretende objetivo e cientificizante, para o espaço da linguagem. E quando essas mesmas ficções desaguam no espaço da consciência linguística graças ao papel desempenhado pela metáfora, elas, enquanto figuras da imaginação produtora ou transcendental (WUNENBURGER, 1991, p. 15-19), tendem a representar uma fonte de enriquecimento para a construção dos diferentes tipos de racionalidade, seja ela científica ou mais de cunho hermenêuticofilosófico (o domínio privilegiado do conceito abstrato).

Se da metáfora importa reter que ela ocorre "no universo já purificado do logos" (RICOEUR, 1987, p. 71) e que tem o poder de relacionar a superfície semântica com a superfície pré-semântica do símbolo, já do símbolo aquilo que importa reter é que ele "hesita na linha divisória entre o bios e o logos", ou seja, "mergulham as suas raízes nas constelações duradouras da vida do sentimento e do universo" (RICOEUR,1987, p. 71-76). Neste sentido, não pensamos que seja ousado afirmar que os reagentes da imaginação (uma espécie de "hormonas" da imaginação pensando em Bachelard) identificam-se com a metáfora viva e com o símbolo. E estas figuras pregnantes simbolicamente (lembrando aqui Ernst Cassirer) ao estarem presentes, de uma forma, ou de outra, nos textos educacionais e pedagógicos de Reboul, 1994; Low, 2010; Scheffler, 1970; Hameline, 1986; Charbonnel, 1991a, 1993, 1989; Sticht, 1996, não serão já elas uma espécie de alter-ego da própria imaginação? Os textos que falam da educação não 
podem passar sem a voz da metáfora e o olhar do símbolo porque aquilo que de mais dramático pode acontecer é assistir-se a "uma educação sem símbolos face a símbolos sem educação" (REBOUL, 1992, p. 217-219). É precisamente para contrariar a possibilidade de uma educação sem símbolos e metáforas ou, no limite, uma educação habitada por símbolos e metáforas mortas que escolhemos o exemplo da metáfora agrícola para ilustrar que a educação enquanto fenômeno humano. A relação educativa dificilmente pode deixar de ser imaginada como um "percursodeslocamento" (metáfora da viagem terrestre, náutica etc.), como um "enchimento-alimentação", como um "crescimento ou cultura vegetal" (metáforas agrícolas), como "luz" em movimento, como modelagem7, entre outro tipo de metáforas. Na educação as metáforas são utilizadas pelos pedagogos, ou mesmo filósofos da educação, mais ou menos voluntariamente, e no limite involuntariamente ${ }^{8}$, para melhor dar a ver, para melhor ilustrar, quase que sensitivamente, quase que opticamente, a relação simbiótica e simbólica entre a educação como cultura da criança e o ciclo naturalista que começa com o lançamento da semente, já numa terra previamente preparada, até ao gradual crescimento da planta que, à semelhança da criança, também ela um dia se tornará numa flor ou mesmo numa árvore adulta. Evê-se por aqui que em educação não se pode fugir ao poder da metáfora, particularmente àquilo que Daniel Hameline designou por "a grande sonharia [songerie no original] hortícola" (HAMELINE, 1986, p. 182-185). A metáfora hortícola tem o dom heurístico de nos transportar, de nos fazer percorrer, através de um desvio semântico (HAMELINE, 1981), desde o sentido figurado, passando pelo questionamento do sentido da formação humana (GENNARI, 2006), até àquilo que Hameline designou de crença fundamental, estruturante, originária: "se qualquer coisa é transportável de uma palavra a outra, se o aluno é, num sentido, uma planta que cresce, é que entre o aluno e a planta existe uma analogia que não é de modo algum da ordem da ornamentação do discurso, mas antes da ordem do ser" (HAMELINE, 1981, p.123).

7 Nanine Charbonnel chama a atenção para o seguinte leque de metáforas no discurso educativo: "Escultura e olaria, alimentação e enchimento, jardinagem, agricultura, domesticação, artesanatos diversos, marcha e navegação" (CHARBONNEL, 1983, p. 157).

8 A este respeito, vejam-se as palavras de Daniel Hameline (1986, p. 182) "Mas o caráter próprio da metáfora, é que aqueles que a usam a desejam não metafórica. É uma verdade fundadora que a comparação se encarrega de professar". O que significa portanto que muitos autores nem mesmo admitiam que nos seus escritos o jogo metafórico naturalista pudesse desempenhar um papel outro que o mero efeito estilístico ou retórico. 


\title{
A dinâmica da imaginação simbólica no psiquismo imaginante
}

A imaginação, segundo Gilbert Durand, cumpre a importante função de eufemização com o seu poder de transformação:

\begin{abstract}
A imaginação simbólica é dinamicamente negação vital, negação do nada da morte e do tempo. [...] a função da imaginação é antes de mais uma função de eufemização, não um simples ópio negativo, máscara que a consciência ergue face à horrenda figura da morte, mas pelo contrário dinamismo prospectivo, que através de todas as estruturas do projeto imaginário, tenta melhorar a situação do homem no mundo (DURAND, 1979, p.119-122).
\end{abstract}

Esta função não só se submete ao antagonismo dos regimes do imaginário (DURAND, 1984), como não pode deixar de usar as figuras semânticas da retórica, tais como a antítese para o regime diurno e a antífrase para o regime noturno, para melhor se exprimir. Assim, "a imaginação simbólica constitui a própria atividade dialética do espírito" (DURAND, 1979, p. 117). As imagens em devaneio criam o nosso ser espiritual, sacodem-no, ou seja, mais do que a vontade ou qualquer élan vital, qualquer que seja ele, é a imaginação que representa a "própria força da produção psíquica" (BACHELARD, 1981, p. 181), e Gilbert Durand questiona-se mesmo: "E se tantos símbolos, tantas metáforas poéticas animam o espírito dos homens, não será, em última análise, porque são as 'hormonas' da energia espiritual?" (DURAND, 1979, p. 117).

E a ser assim, o segredo das "energias mutantes", as mesmas que alimentam a imaginação, que a fazem viver e mover quer ascensionalmente (o sentido anafórico), quer descensionalmente (o sentido catafórico), deve ser procurado na "região da metáfora de metáfora" (BACHELARD, 1981, p. 181), que é uma região onde o"devaneio transforma as formas previamente transformadas" (BACHELARD, 1981, p.181). Da nossa parte, identificamos esta região com a própria imaginação, enquanto reino endógeno e autóctone porque ela, como nos ensinou Bachelard, é a "faculdade de deformar as imagens fornecidas pela percepção, ela é, sobretudo, a faculdade de libertar-nos das imagens primeiras, de mudar as imagens" (BACHELARD, 2004, p. 5; WUNENBURGER, 2012, p. 30-33) e não como sempre se pretende que ela seja a faculdade de formar imagens. É esta faculdade assim definida 
que permitirá ao sujeito na sua atividade imaginante explorar os vetores simbólicos e as valências afetivas da imagem. Neste contexto, perguntase se as novas imagens surgidas da deformação provocada pela própria imaginação não obedecerão elas a uma lógica?, Não terão elas uma organização específica?, Não obedecerão elas a estruturas figurativas próprias e ativas?

A resposta a estas questões surgem-nos do lado de Gilbert Durand (1984), que propôs nas suas Les Structures Anthropologiques de L'Imaginaire uma espécie de gramática iconológica que obedece a uma lógica de imagens e esta, por sua vez, conjuga uma"semântica arquetipal" (e não existencial) com uma sintaxe simbólica (não formalista), a qual recebeu o nome de "Classificação Isotópica das Imagens": é constituída por dois regimes de imagem (diurno e noturno) e por três estruturas antropológicas que configuram o imaginário (estruturas esquizomorfas ou heroicas (DURAND, 1984), estruturas sintéticas ou dramáticas e as estruturas místicas ou antifrásicas Estas orientações conduzem a que a imaginação não imagine qualquer coisa, ela não é a folle du logis (Malebranche), nem, como o pretendia Pascal, a maîtresse d'erreur et de fausseté, a imaginação (que não deve ser confundida com a fantasia (fancy) produz as suas obras de acordo com a gramática iconológica tal como a elaborou o próprio Gilbert Durand:

O imaginário humano não imagina qualquer coisa, ele não é de forma nenhuma uma 'imaginação' inesgotável, senão uma 'obra de imaginação' - e elas são-no todas! - não poderia jamais transmitir-se, comunicar-se e, finalmente, 'traduzir-se'. O preço da universalidade do imaginário é a sua limitação (DURAND, 1998, p. 255).

Compreende-se, assim, que a imaginação não seja uma faculdade caótica, arbitrária, contingente e que o imaginário por si destilado possa ser mesmo universalizado:

O vocábulo fundamental que corresponde à imaginação não é imagem, mas imaginário. $O$ valor de uma imagem mede-se pela extensão da sua auréola imaginária. Graças ao imaginário, a imaginação é essencialmente aberta, evasiva. É ela, no psiquismo humano, a própria experiência de abertura, a própria experiência da novidade. (DURAND, 2004, p. 5-6). 
As imagens produzidas pelo psiquismo imaginante ora pertencem à imaginação reprodutora (o domínio da imagem percepcionada, da percepção e da memória), ora pertencem à imaginação criadora (domínio da imagem criada-imagem imaginada (BACHELARD, 1976) e aquelas que provêm da imaginação criadora são as mais estimulantes e desafiantes para o sujeito imaginante mergulhar naquilo que Gilbert Durand (1984) designou de "fantástica transcendental". A imaginação criadora dispõe da função do "irreal" (BACHELARD, 1976) que lhe assegura precisamente o poder que o sujeito imaginante dispõe de "deformar as imagens fornecidas pela percepção" como o pretendia, aliás, Bachelard (1976, p. 4) "As imagens imaginadas são sublimações dos arquétipos em vez de reproduções da realidade". E são precisamente estas imagens primigênias, arquetípicas produzidas pela imaginação criadora que fornecem todo um material onírico e simbólico (Gilbert Durand falaria de uma arquetipologia geral) que justamente servirá de base para que Durand possa ter forjado o "quadro da classificação isotópica das imagens" onde as imagens são tipificadas de acordo com os conteúdos semânticos, com as estruturas sintáticas e com os seus valores afetivos (DURAND, 1984, p. 506-507). No entanto, mesmo que o quadro atrás referido nos permita melhor compreender como as imagens se organizam e se classificam de modo a que a imaginação simbólica não se converta numa folle du logis (Malebranche) seja por defeito de imagens (hipotrofia), isto é, aquele sujeito privado de simbolizar dominado pelo poder do signo, seja por excesso (hipertrofia), isto é, refere-se àquele indivíduo que tem uma imaginação de tipo delirante e cacofônico. Como se entende, não é pela simples existência do quadro mencionado que o sujeito imaginante de per si escape às formas patológicas da imaginação atrás referidas e que delas escape ainda que as estudando com afinco, pois a monopolização e a despolarização mental são sempre passíveis de infetar o sujeito imaginante (WUNENBURGER, 1991; DURAND, 1981). Seria, aliás, muito ingênuo pensar que, pela simples idealização e existência do "quadro isotópico das imagens", a imaginação pudesse, por um lado, apresentarse como uma combinatória de imagens bem organizadas e previsível na sua organização sintática e semântica, e, por outro lado, esquivar-se de sua natureza equívoca e ilusória, de modo estar livre de toda a suspeita e desconfiança que inspira nas correntes racionalistas, positivistas de tipo iconoclasta. Isso seria esquecer que a imaginação é uma 
[...] faculdade complexa, ambivalente, mesmo contraditória nos seus efeitos como nos seus modos de funcionamento. Por um lado, ela é capaz de elaborar as redes simbólicas autónomas e coerentes, formando verdadeiramente 'um mundo', mas de outro, pela sua forte potência de impressão e de expansão, ela submete o sujeito a uma sucessão desconfortável de reações, de adesão e de recusa. Além disso, a imaginação aparece simultaneamente como ligada, coagida pelos núcleos simbólicos das estruturas formais, dos tropismos afetivos, e como livre, sendo arrastada e guiada por um Eu voluntário, um Cogito de onirismo (WUNENBURGER, 1991, p. 85-86).

Sendo então a imaginação uma faculdade tão complexa, ela tende naturalmente a escapar pela sua própria natureza multívoca, fugidia (porque contém, em si, o dom da metamorfose) e plástica (uma das suas funções é a da eufemização) a uma gramática por mais que ela se revele pertinente e pregnante simbolicamente, como é o caso da "classificação isotópica das imagens" estabelecida por Gilbert Durand que nos permite compreender de modo aprofundado a "lógica das imagens" (WUNENBURGER, 1991). Por isso mesmo, é da natureza íntima, congênita da imaginação ser sempre imprevisível, desafiadora, assustadora, apaziguadora, eufemizadora etc., porque se assim não fosse a imaginação não seria mais do que um estado petrificado de imagens agrilhoadas a uma percepção rotineira, senão mesmo a uma forma de imaginário mecânico, estereotipado e mórbido (imaginário atrofiado, anêmico, empobrecido, estereotipado, traumático, obsessivo...) (WUNENBURGER, 2011), o que não corresponde de todo àquilo que dela se espera enquanto "rainha das faculdades" (Baudelaire), ou como, lembrando William Blake, encarnando a própria existência humana. A este respeito, nunca é demais sublinhar que aquilo que da imaginação se espera é que ela seja capaz de transformar as imagens fornecidas pela percepção porque

Se não há mudança de imagens, união inesperada de imagens, não há imaginação, não há ação imaginante. Se uma imagem presente não leva a pensar numa imagem ausente, se uma imagem ocasional não determina uma prodigalidade de imagens aberrantes, uma explosão de imagens, não há imaginação. Há percepção, recordação de uma percepção, uma memória familiar, hábito de cores e de formas (BACHELARD, 2004, p. 5). 
No entanto, a imaginação pode sempre sofrer o perigo de sinal contrário, isto é, deixar-se embalar pelas suas qualidades de evasão, de audácia, enfim de ausência até a uma "hipertrofia das imagens" cuja principal consequência é de a imaginação produzir um tipo de imaginário exuberante, excessivo, frenético, delirante (WUNENBURGER, 2011). Tal deriva, excêntrica, autossuficiente e ilusória pode conduzir a um estado de loucura e de demência, senão mesmo a uma paixão descontrolada. A imaginação sofrendo desta espécie de patologia aparece desligada, quer do real vivificador (veja-se os quatro elementos de Bachelard enquanto "hormonas da imaginação"), quer do pensamento que a alimenta de uma semântica doadora de sentidos múltiplos e de significações inteligíveis.

Face aos perigos de sinal contrário importa não esquecer que se os caminhos da imaginação podem conduzir alguns ao reino da loucura e da demência, outros poderão por ela e com ela seguirem a via da sua autorrealização, quer dizer, de com a imaginação poderem cumprir plenamente a sua vocação e o seu destino que é o caso das almas artísticas que alimentam a sua atividade criativa de um magma de visões instauradoras de sobrerrealidades, no sentido bachelardiano, assim como estas mesmas visões poderão provir tanto do imaginário (Gilbert Durand) como do imaginal (Henry Corbin) (WUNENBURGER, 2011).

Neste contexto, cabe o alerta de que não basta conhecer o "quadro da classificação isotópica das imagens" criado por Gilbert Durand, que permite compreender a lógica da organização das imagens (WUNENBURGER, 1991, p. 60-65), para tornar-se um criador e acessar o reino da imaginação criadora seja ela transcendental ou suprassensível. A capacidade imaginativa, embora regida, tanto por uma gramática, como por uma lógica bem determinada de imagens, tem que delas se servir, num primeiro momento, para evitar a "hipotrofia e hipertrofia" das imagens, para num segundo momento deixar-se seduzir pela regra do "como se" a fim de escapar, por intermédio da atividade lúdica, à ordem das coisas, do factual e lançar-se na via da diferença e da alteridade que o próprio jogo permite no sentido mais lato e que se traduz nos ritos, nas dramatizações, nas festas, teatralizações e demais práticas artísticas (domínio da imaginação lúdica) (WUNENBURGER, 1991; JEAN, 1991).

Por outras palavras, o sujeito, na sua qualidade de homo ludens (Huizinga) não pode deixar de manter uma relação lúdica consigo, com o mundo, com o outro e com o próprio cosmos e é, portanto, esta relação que o incita a sair do real conhecido para um mundo outro: o mundo do 
faz de conta, do "como se". É a entrada do sujeito neste mundo, com o jogo de imagens que ela despoleta e que lhe está associada, que pode permitir-lhe soltar-se das amarras do cais do real cotidiano e pesado (Mircea Eliade falaria do espaço e do tempo profanos) para, e já de forma iniciática, penetrar no reino da criatividade, das formas inesperadas e inspiradoras onde uma obra de imaginação possa surgir (o domínio do espaço e do tempo sagrados para Eliade):

A imaginação, como o espírito em geral, exige também uma espontaneidade que garante a invenção e a inovação, pelo intermédio de ruturas e de singularizações que tocam à exceção. $A$ imaginação é uma manifestação sempre um pouco imprevisível do psiquismo, que nunca está longe do ingenium, do 'génio' no sentido de uma emergência de imagens que se enraízam nos recantos mais obscuros daquilo que outrora se chamava alma. (WUNENBURGER, 2011, p. 42).

\section{A pedagogia da imaginação e a formação imaginante do sujeito}

É neste contexto que a pedagogia da imaginação faz sua aparição, e faz sentido assim o ser porque ela é a melhor garantia do sujeito imaginante precaver-se da armadilha "hipo" (trofia) e "hiper" (trofia) das imagens e seguir, ao contrário, a via da imaginação como portadora de conteúdos de pensamento que possam, mediante imagens simbólicas, exprimir-se de um modo original (o domínio da "alteridade"), escapando desta forma ao jogo mimético que insiste na "mesmidade" e no "idêntico".

Resumidamente, espera-se que uma pedagogia da imaginação trabalhe a "intenção simbolizante" (WUNENBURGER, 1991, p. 65-72) do sujeito imaginante de modo que ela não seja vítima quer da atitude iconoclasta das imagens (sua hipotrofia), quer da atitude idólatra (sua hipertrofia) (DURAND, 1980). O que se pretende da pedagogia da imaginação é que ela ensine e oriente o sujeito imaginante a realizar uma síntese entre essas duas disposições, que são dois extremos patológicos da própria "intenção simbolizante". Sob a direção de uma pedagogia da imaginação espera-se que esse mesmo sujeito proceda de acordo com dois dos princípios queridos da hermetica ratio, que são o princípio do "terceiro incluído" (tertium datur) e o "princípio de similitude" 
(que é outro nome para o princípio da "coincidência dos contrários" coincidentia oppositorum) (DURAND, 1979; WUNENBURGER, 1990), de modo a fundir ou integrar criativamente numa "coesão antagonista de contrários" os dois polos em "hipo" (homogeneização das imagens) e em "hiper" (heterogeneização das imagens) da relação com as imagens. Se da coesão dos polos heroico e místico das "estruturas antropológicas do imaginário" surgiu o disseminatório (também conhecido como sintético ou dramático), espera-se que, de modo semelhante, se possa chegar a uma terceira margem que faça subsumir a tensão "bipolar" de ambas as atitudes unilaterais irredutíveis em ordem não a uma dialética, nem a uma complementaridade, mas sim a uma tensão antagonista e coerente entre os polos contrários ${ }^{9}$, ou seja, entre duas polaridades antagonistas constitutivas da "intenção simbolizante"10.

Para que tal seja possível, a pedagogia da imaginação tem que ensinar o uso, embora reconheçamos que a sua tarefa não seja fácil devido à educação nos moldes da tradição da lógica aristotélica, um tipo de lógica diferente da lógica clássica do "terceiro excluído" ou simplesmente "bivalente" aristotélica, para de modo não aristotélico, não cartesiano e não newtoniano mostrar que a via da lógica dos antagonistas (aquilo que Stéphane Lupasco designou por "lógica da heterogeneidade" ou do "contraditório") é aquela que pode superar o nosso problema:

Em resumo, nós podemos dizer que no domínio 'mental', tanto individual como coletivo, psicológico como sociológico, só há polaridade verdadeira quando há tensão heterogénea entre os sistemas de representação separadamente homogéneos. Tal parece ser, entre outros, a lei do espírito humano. Esta pluralização antagonista e polarizante carateriza toda a obra humana, da modesta construção da pessoa ao estabelecimento e à perenidade das cidades, dos impérios e das civilizações (DURAND, 1980, p. 66).

9 Gilbert Durand (1980, p. 57) em relação a esta "coerência antagonista" não deixa de alertar que ela não deve ser confundida nem com a antiga dialética, nem com a ideia de complementaridade.

10 Lembramos que Nietzsche tinha na sua obra A Origem da Tragédia no Espírito da Música (1872) falado de Apolo e de Dioniso como sendo duas polaridades antagonistas constitutivas da alma grega e depois dele, entre outros (pensamos por exemplo em Georges Dumézil), Jung que com as suas noções de animus e de anima nos alertou igualmente para a sua irredutibilidade que espera por uma espécie de coerência salvífica. Em ambos os casos constata-se da importância heurística do sistema de tensões de antagonismos irredutíveis. 
A imaginação apela, portanto, a uma pedagogia que lhe diga qual a melhor maneira dela contribuir para a "formação" (no sentido do conceito alemão de Bildung) de um eu que tenha a lucidez tanto de virar as costas a um racionalismo dogmático e integrista como a uma ideologia espontaneísta e naturista (WUNENBURGER, 1991; DUBORGEL, 1992) ambas as atitudes se arriscam a formar um cogito de um sonhador de pesadelos, alguém perdido no seu sono letárgico. Daí que, por um lado, Bruno Duborgel, na linha de Gaston Bachelard, tenha instaurado uma pedagogia própria à imaginação e ao imaginário apta a ensinar o sujeito imaginante a interpretar o sentido das imagens que ele próprio cria, bem como outras que ele também vai descobrindo nas suas atividades criativas e sociais, daí que o autor afirme que a pedagogia do imaginário (nós diríamos da imaginação) é uma pedagogia do "pleno" (nós diríamos antes da plenitude) que ensina o sujeito imaginante, ao longo da sua vida escolar e acadêmica, a usufruir, a meditar sobre o recheio imenso (um império das imagens nos seus diferentes suportes) existente no "museu imaginário" (André Malraux) do homo symbolicus (Ernst Cassirer) no seu sentido mais amplo, como lhe confere Gilbert Durand quando o concebe como "um inventário geral dos recursos imaginários, uma arquetipologia geral" (DURAND, 1984, p.497), e também como

[...] um recenseamento total dos temas, dos ícones e das imagens, num Museu imaginário generalizado a todas as manifestações culturais. [...] Por detrás do 'Museu imaginário' no sentido restrito, o dos ícones e das estátuas, é preciso considerar, generalizando, um museu mais vasto que é o dos 'poetas'. A antologia generaliza o museu. (DURAND, 1979, p. 127-128; DUBORGEL, 1992, p. 239-244).

Porém, para que este"museu imaginário"seja sempre visitado eas suas obras absorvidas e fonte de inspiração, importa, ainda nas palavras de Bruno Duborgel, que a finalidade do "Novo Espírito Pedagógico" da imaginação vise, antes de tudo, a "todo o ato de uma leitura dinâmica, encantada e criadora" (1992, p. 251). Aquilo que se espera desta leitura encantada é que ela seja perturbadora e possa ressoar no transfundo arquetipal do sujeito imaginante de tal modo que este faça da "poética do devaneio" (Gaston Bachelard) o seu programa não só de reflexão e de ação, mas como um programa existencialmente poético e onírico (BACHELARD, 1984; DUBORGEL, 1992). 
Uma pedagogia do imaginário convidativa da criação e da exploração parece, na verdade, adequar-se ao propósito pedagógico pretendido pelo "museu imaginário", pois ele não só espera ser visitado e "olhado" reflexivamente, mas muito particularmente "olhado" imaginativamente. Este conhecimento reflexivo-imaginativo, alimentado pela coleção desse museu (ícones, estátuas e demais esculturas, lendas, mitos, pinturas, contos, símbolos iconográficos, literatura e poemas), deve constituir, em si, uma ocasião e um desafio para que o sujeito imaginante torne-se, ele próprio, também um criador de imagens e não apenas um erudito e contemplador de imagens. Mas para que tal possa acontecer o sujeito imaginante não necessita somente de dispor de "tempo livre" (que paradoxalmente encontra-se cada vez mais ocupado pela idolatria e jugo do trabalho, mesmo quando o homo laborans não está já mais lavorando), mas muito especialmente de "olhos férteis", para usar aqui uma expressão querida a George Jean (1991), para eles verem não só que lá está no "museu", mas, sobretudo, o que a obra humana, em si, esconde, daí que Gilbert Durand tenha dito:

Ao lado da cultura física e da do raciocínio, parece-nos que uma pedagogia da imaginação se impõe. [...] Então, impõe-se uma educação estética, totalmente humana, como uma educação fantástica à escala de todos os fantasmas da humanidade. [...] Também é necessário desejar que uma pedagogia venha iluminar, senão satisfazer esta sede irreprimível de imagens e de sonhos. O nosso dever mais imperativo é de trabalhar para uma pedagogia da preguiça, do relaxamento e dos lazeres (1984, p. 497-498).

Pensar, e, sobretudo, praticar uma pedagogia da imaginação não é, e não pode ser, uma tarefa restrita à escola, como instituição de ensino conduzida ou legislada pelo Estado, cujos interesses afinam-se a uma cultura da produtividade cada vez mais galopante e englobante, que não reserva tempo e espaço para o cultivo do espírito, das artes e da fruição estética, mas deve ser um objetivo de toda a sociedade, um compromisso mesmo da humanidade no sentido de sua autopreservação. Constitui-se, inegavelmente, num desafio imenso, mas supostamente realizável, pois a imaginação jamais deixou de operar a favor do enriquecimento simbólico do museu imaginário. A questão é tornar propício o momento para que a pedagogia da 
imaginação possa exercer uma pressão pedagógica capaz de se impor frente às dificuldades do tempo presente.

\section{Referências}

ALLEAU, René. A Ciência dos Símbolos. Tradução de Isabel Braga. Lisboa: Edições 70, 1982.

ARAÚJO, Alberto Filipe. Educação e Imaginário: Da criança mítica às imagens da infância. Maia: Instituto Superior da Maia, 2004.

BACHELARD, Gaston. La flamme d'une chandelle. Paris: PUF, 1961.

La Terre et les Rêveries de la volonté. 8. Réimp. Paris: Lib. José Corti, 1976.

. La psychanalyse du feu. Paris: Gallimard, 1981.

La poétique de la rêverie. 8. ed. Paris: PUF, 1984.

. L'Eau et les Rêves: Essai sur l'imagination de la matière. Paris: Le Libre de Poche, 1993.

. L'Air et les Songes: Essai sur l'imagination du mouvement. Paris:

Le Libre de Poche, 2004.

BIERDERMANN, Hans. Encyclopédie des Symboles. Paris: Librairie Générale Française, 1996.

CHARBONNEL, Nanine. La Tâche aveugle. Pensée de l'Éducation et Philosophie de la Métaphore. Strasbourg: Presses Universitaires de Strasbourg, 1989. 2. v.

. Les Aventures de la Métaphore. In: La Tâche aveugle.

Strasbourg: Presses Universitaires de Strasbourg, 1991. 1.v.

L. L'important c'est d'être propre. In: La Tâche aveugle.

Strasbourg: Presses Universitaires de Strasbourg, 1991a. 2.v.

- Philosophie du Modèle. In: . La Tâche aveugle. Strasbourg: Presses Universitaires de Strasbourg, 1993. 3.v.

. Freinet ou une Pensée de la Similitude. In: La Pédagogie

Freinet: Mises à Jour et Perspectives. Clanché P., DebarbieuxÉ., Testanière J. (sous la dir. de). Bordeaux: Presses Universitaires de Bordeaux, 1994. 
CHEVALIER, Jean; GHEERBRANT, Alain. Dicionário dos Símbolos. Trad. de Cristina Rodriguez e Artur Guerra. Lisboa: Teorema, 1994.

DUBORGEL, Bruno. Imaginaire et pédagogie. Toulouse: Editions Privat, 1992.

DURAND, Gilbert. A imaginação simbólica. Tradução de Maria de Fátima Morna. Lisboa: Arcádia, 1979.

. L’Âme Tigrée: Les pluriels de psyché. Paris: Denoël/Gonthier, 1980.

Mito, Símbolo e Mitodologia. Lisboa: Presença, 1981.

Les Structures Anthropologiques de I'Imaginaire. Introduction à l'archétypologie générale. 10. ed. Paris: Dunod, 1984.

. Campos do Imaginário. Textos reunidos por Danièle Chauvin. Tradução de Maria José Batalha Reis. Lisboa: Instituto Piaget, 1998.

. O Imaginário: ensaio acerca das ciências e da filosofia da imagem. Rio de Janeiro: DIFEL, 2004.

ELIADE, Mircea. Tratado de História das Religiões. Trad. de Fernando Tomaz e Natália Nunes. 2. ed. Porto: Asa, 1994.

FREINET, Célestin. CEuvres Pédagogiques. Tomes 1/2. Paris: Du Seuil, 1994.

GENNARI, Mario. Formazione. In: . Enciclopedia Filosofica. Milano: Bompiani, 2006.

JEAN, Georges. Pour une pédagogie de l'imaginaire. Paris: Casterman, 1991.

HAMELINE, Daniel. Place et fonction de la métaphore dans la pensée sur l'éducation ou éloge de la rhétorique. Éducation et Recherche, 1981.

. L'Éducation, Ses Images et Son Propos. Paris: ESF, 1986.

LOW, Graham. Metaphor and education. In: GIBBS Jr.; RAYMOND, W. The Cambridge Handbook of Metaphor and Thought. Cambridge: Cambridge University Press, 2010.

REBOUL, Olivier. Les valeurs de l'éducation. Paris: PUF, 1992. . Introduction à la rhétorique. 2. ed. Paris: PUF, 1994. 
RICOEUR, Paul. La métaphore vive. Paris: Seuil, 1997.

. Teoria da interpretação: o discurso e o excesso de significação. Tradução de Artur Morão. Lisboa: Edições 70, 1987.

Philosophie de la volonté. II Finitude et culpabilité. Paris: Aubier, 1988.

STICHT, Thomas G. Educational uses of metaphor. In: ORTONY, Andrew (ed). Metaphor and thought. Cambridge: Cambridge University Press, 1996.

WUNENBURGER, Jean-Jacques. La raison contradictoire. Sciences et philosophie modernes : la pensée du complexe. Paris: Albin Michel, 1990. . L'Imagination. Paris: PUF, 1991.

. La « Bildung » ou l'imgination dans l'éducation. In: BOUVERESSE, Renée (Org). Education et philosophie. Écrits en I'honneur d'Olivier Reboul. Paris: PUF, 1993.

. L'Imagination Mode d'Emploi. Paris : Éditions Manucius, 2011.

Gaston Bachelard. Poétique des Images. Paris: Mimesis, 2012.

Recebido em: outubro/2016

Aprovado em: dezembro/2016 